Article

\title{
Evaluation of Napier Grass for Bioethanol Production through a Fermentation Process
}

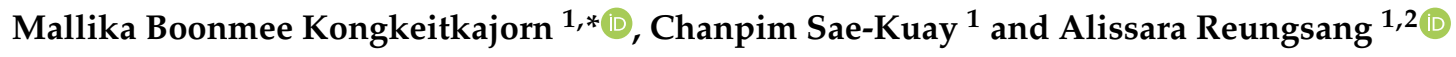 \\ 1 Department of Biotechnology, Faculty of Technology, Khon Kaen University, Khon Kaen 40002, Thailand; \\ chanpim0112@gmail.com (C.S.-K.); alissara@kku.ac.th (A.R.) \\ 2 Research Group for Development of Microbial Hydrogen Production Process, Khon Kaen University, \\ Khon Kaen 40002, Thailand \\ * Correspondence: mallikab@kku.ac.th
}

Received: 12 April 2020; Accepted: 7 May 2020; Published: 11 May 2020

\begin{abstract}
Ethanol is one of the widely used liquid biofuels in the world. The move from sugar-based production into the second-generation, lignocellulosic-based production has been of interest due to an abundance of these non-edible raw materials. This study interested in the use of Napier grass (Pennisetum purpureum Schumach), a common fodder in tropical regions and is considered an energy crop, for ethanol production. In this study, we aim to evaluate the ethanol production potential from the grass and to suggest a production process based on the results obtained from the study. Pretreatments of the grass by alkali, dilute acid, and their combination prepared the grass for further hydrolysis by commercial cellulase (Cellic $\left.{ }^{\circledR} \mathrm{CTec} 2\right)$. Separate hydrolysis and fermentation (SHF), and simultaneous saccharification and fermentation (SSF) techniques were investigated in ethanol production using Saccharomyces cerevisiae and Scheffersomyces shehatae, a xylose-fermenting yeast. Pretreating $15 \% w / v$ Napier grass with $1.99 \mathrm{M} \mathrm{NaOH}$ at $95.7^{\circ} \mathrm{C}$ for 116 min was the best condition to prepare the grass for further enzymatic hydrolysis using the enzyme dosage of 40 Filter Paper Unit (FPU)/g for $117 \mathrm{~h}$. Fermentation of enzymatic hydrolysate by S. cerevisiae via SHF resulted in the best ethanol production of $187.4 \mathrm{~g} / \mathrm{kg}$ of Napier grass at $44.7 \mathrm{~g} / \mathrm{L}$ ethanol concentration. The results indicated that Napier grass is a promising lignocellulosic raw material that could serve a fermentation with high ethanol concentration.
\end{abstract}

Keywords: Napier grass; bioethanol; biomass fractionation; enzyme hydrolysis; acid pretreatment; alkali pretreatment

\section{Introduction}

Napier grass (Pennisetum purpureum Schumach), known also as elephant grass, is a perennial grass found in tropical regions. Its high yield, easy cultivation, nutrient availability and versatility make it widely popular for use as a fodder crop. Annual production yields of the grass vary depending on cultivars, harvest cycles, fertilization, and climates. The reported Napier grass yield in temperate climates was 20-40 ton/ha [1], while the yield in tropical climates was higher at 50-67 ton/ha [2,3]. Napier grass is classified as a lignocellulosic biomass. Its structural compositions varies depending on weather, variety, and age. Reports on its composition covered $31-41 \%$ cellulose and $15-47 \%$ hemicellulose [4-7]. Hydrolysis of its structure yields glucose and xylose, which are monomeric sugars that serve as substrates in microbial fermentation to produce various biochemical including biofuels.

Napier grass plantation in Thailand has been for agricultural purposes. As the country has continuously promoted biofuel production, Napier grass is considered as an energy crop. Thailand's 10 Year (2012-2021) Alternative Energy Development Plan has placed the grass as one of the focused energy plants [8]. Napier grass has been successfully used in biogas production [8-10]. 
Studies on the use of Napier grass for other biofuels production also exist, including for bioethanol production. Pretreatments play an important role in production of liquid fuels. A study showed a higher ethanol yield when using pretreated versus non-pretreated grasses, mainly due to increases in sugar yields obtained in hydrolysis [11].

Pretreatment of Napier grass is an important step to prepare it for further hydrolysis. The process alters physical structure of the biomass so that enzyme has a better access to the cellulose chain of the biomass and improves hydrolysis [12,13]. Studies have been investigating various methods of pretreatment, primarily physical and chemical methods, with the aim to obtain high sugar yields. Some examples of the pretreatments focused on Napier grass included the uses of various alkalis, e.g., aqueous ammonia, $\mathrm{Ca}(\mathrm{OH})_{2}, \mathrm{NaOH}$, alkali $\mathrm{H}_{2} \mathrm{O}_{2}$ [14-16], and ammonia gas [17,18], dilute acid [14], acid-peroxide [19], acid-alkali [20], steam explosion [14,21], hydrothermal treatment [11], and nitrogen explosive decompression [22].

In the current study, we attempted to determine a simple and viable process for ethanol production from Napier grass. The works in each pretreatment and hydrolysis step involved the use of response surface methodology in order to determine the suitable conditions for each pretreatment and hydrolysis routes.

Despite various pretreatment methods available, we chose to investigate the chemical pretreatment of mechanically ground Napier grass due to its operational simplicity. We also chose $\mathrm{NaOH}$ and $\mathrm{H}_{2} \mathrm{SO}_{4}$ as they are common chemicals that are already in use by industries. The suitable conditions for enzymatic hydrolysis of the each pretreatment methods were then determined to obtain the process that resulted in the highest sugar released from the grass. Upon obtaining suitable pretreatment and hydrolysis conditions, ethanol production was investigated using hydrolysate obtained from enzymatic hydrolysis of pretreated grass, through separated hydrolysis and fermentation (SHF), and using the pretreated grass, through simultaneous saccharification and fermentation (SSF). Two yeast strains were used in fermentations, a common yeast and a xylose-fermenting yeast. We evaluated the ethanol production using such combination of substrates and yeasts and suggested the process for ethanol production from Napier grass based on the results of the study.

\section{Materials and Methods}

\subsection{Preparation of Napier Grass}

Napier grass (Pennisetum purpureum Schumach) Pakchong 1 aged 90-150 days was harvested from the Demonstration field of the Faculty of Agriculture, Khon Kaen University, Thailand. Stems were cut approximately $5 \mathrm{~cm}$ above the ground. They were then chopped and oven dried at $70^{\circ} \mathrm{C}$. The dried stems were then milled and sieved through a 10-mesh screen to obtain dried grass used in the study.

\subsection{Alkali and Dilute Acid Pretreatments}

Pretreatments using alkali and acid followed a similar procedure. In the case of alkali pretreatment, dried Napier grass was soaked in $200 \mathrm{~mL}$ sodium hydroxide solution at $15 \%$ w/v loading in $500 \mathrm{~mL}$ high-pressure laboratory bottles and heated in an autoclave. For acid pretreatments, dried Napier grass or alkali-pretreated grass was soaked in sulfuric acid and heated in an autoclave. The concentration, time, and temperature of the pretreatment were varied according to the values shown in Table 1 . After pretreatment, solid fractions were collected and washed until the $\mathrm{pH}$ was neutral. They were then dried at $70{ }^{\circ} \mathrm{C}$ prior to analysis and enzymatic hydrolysis.

Design Expert ${ }^{\circledR}$ (version 7.0 demo, Stat-Ease, Minneapolis, MN, USA, 2005) was used in designing the experimental runs and analysis of results. Box-Benkhen design was applied for all experiments. Treated grasses were analyzed for their susceptibility to cellulase hydrolysis which was used as responses in all pretreatments. Mathematical models obtained from program analysis were used to predict the conditions that resulted in the highest susceptibility for each of the pretreatment methods. 
Table 1. Factors and levels used in pretreatment and enzymatic hydrolysis studies.

\begin{tabular}{cccc}
\hline Treatment Methods & Factors & Low Level (-1) & High Level (+1) \\
\hline Alkali pretreatment & NaOH, Molarity $(\mathrm{M})$ & 0.25 & 3 \\
& Temperature, ${ }^{\circ} \mathrm{C}$ & 50 & 100 \\
& Time, min & 30 & 180 \\
\hline Acid pretreatment & $\mathrm{H}_{2} \mathrm{SO}_{4}, \%$ \% $/ v$ & 1 & 5 \\
& Temperature, $^{\circ} \mathrm{C}$ & 80 & 120 \\
& Time, min & 30 & 120 \\
\hline Acid pretreatment & $\mathrm{H}_{2} \mathrm{SO}_{4}, \%$ \% $/ v$ & 5 \\
of alkali-treated grass & Temperature, $^{\circ} \mathrm{C}$ & 1 & 100 \\
& Time, min & 50 & 180 \\
\hline \multirow{2}{*}{ Enzymatic hydrolysis } & Enzyme dosage (Filter Paper & 60 & 50 \\
& Unit (FPU)/g substrate) & 10 & 120 \\
& Incubation time, $\mathrm{h}$ & 24 & 15 \\
\hline
\end{tabular}

\subsection{Enzymatic Hydrolysis}

Pretreated grasses were hydrolyzed using a cellulase, Cellic ${ }^{\circledR}$ CTec2 (Novozymes, Bagsvaerd, Denmark). Grass was added into $100 \mathrm{~mL}$ of $50 \mathrm{mM}$ citrate buffer solution (pH 5.0) in a 500-mL laboratory bottle. The enzyme was then added and mixed, and the mixture was incubated in a water bath at $50{ }^{\circ} \mathrm{C}$ with constant mixing. The hydrolysis reaction was stopped by boiling the content for $5 \mathrm{~min}$. The liquid fraction was analyzed for reducing sugar.

Operation factors that were evaluated in enzymatic hydrolysis included enzyme dosage, incubation time and substrate loading (Table 1). The Box-Benkhen design was used in designing experimental runs with the help of Design Expert ${ }^{\circledR}$ software (version 7.0 demo, Stat-Ease, Minneapolis, MN, USA, 2005). The analysis of data was also carried out using the program. Suitable conditions for hydrolysis by the enzyme were determined based on the maximum amount of reducing sugars obtained from model prediction.

\subsection{Ethanol Fermentation via SHF and SSF}

Saccharomyces cerevisiae TISTR 5339 (Thailand Institute of Scientific and Technological Research, Bangkok, Thailand) and Scheffersomyces shehatae ATCC 22984 (The American Type Culture Collection, Manassas, VA, USA) were used in all fermentations. Yeast stocks were maintained in 30\% glycerol. They were propagated twice in Yeast Malt (YM) agar. Liquid medium used in fermentation was prepared from enzymatic hydrolysate of alkali-treated grass supplemented with $2 \mathrm{~g} / \mathrm{L}$ autolyzed yeast powder (FM801, Angel Yeast, Yichang, China) for S. cerevisiae or $6 \mathrm{~g} / \mathrm{L}$ for S. shehatae. Fermentations were carried out in $250 \mathrm{~mL}$ Erlenmeyer flasks.

In inoculum preparation, a few single colonies were inoculated in diluted hydrolysate medium whose glucose was adjusted to $10 \mathrm{~g} / \mathrm{L}$. It was incubated at $30{ }^{\circ} \mathrm{C}$ with shaking at $200 \mathrm{rpm}$ for $24 \mathrm{~h}$. Ten percent of the first seed inoculum was transferred to a fresh hydrolysate medium with $20 \mathrm{~g} / \mathrm{L}$ glucose and incubated at the same conditions for another $24 \mathrm{~h}$.

In separate hydrolysis and fermentation (SHF), $10 \mathrm{~mL}$ of inoculum was transferred to $100 \mathrm{~mL}$ of hydrolysate medium. For simultaneous saccharification and fermentation (SSF), $100 \mathrm{~mL}$ of $15 \% w / v$ slurry of alkali-treated grass in water, supplemented with autolyzed yeast powder, were used as substrate and medium for fermentation. Ten $\mathrm{mL}$ of inoculum was added together with 40 Filter Paper Unit (FPU)/ggrass of cellulase, Cellic ${ }^{\circledR}$ CTec2, to start the cultivation. Fermentation conditions were $30{ }^{\circ} \mathrm{C}$ with shaking at $100 \mathrm{rpm}$. Samples were taken at intervals and analyzed for cell growth, sugars, and ethanol concentrations. 


\subsection{Analysis}

Grasses after pretreatment were analyzed by assessing their susceptibility to cellulase hydrolysis ("susceptibility test" in short). One gram of dried grass was hydrolyzed by $30 \mathrm{FPU} / \mathrm{g}$ of cellulase (Cellic ${ }^{\circledR} \mathrm{CTec}$ ) in $50 \mathrm{mM}$ citrate buffer (pH 5.0) for $72 \mathrm{~h}$ at $50{ }^{\circ} \mathrm{C}$. Results from the analysis were reported as susceptibility with the unit of gram of reducing sugar per liter $\left(g_{R S}\right.$, suscepibility $\left./ L\right)$.

Structural compositions of grasses before and after pretreatments were analyzed based on extractive-free biomass following the NREL procedure [23] and ASTM standard test E1758-01(2007). Surfaces of grasses were observed under scanning electron microscope (S-3000N, Hitachi, Tokyo, Japan).

Number of cells was reported as cells/mL and determined using cell count on hemocytometer. Reducing sugar was analyzed using dinitrosalicylic acid colorimetric assay. High-performance liquid chromatography (LC-20A, Shimadzu, Kyoto, Japan) was used to determine concentrations of glucose, xylose, and ethanol. It was equipped with an Aminex HPX-87H (Bio-Rad, Hercules, CA, USA) column and a refractive index detector (RID-6A, Shimadzu, Kyoto, Japan) for analysis. Column temperature was set at $40{ }^{\circ} \mathrm{C}$. The mobile phase was $5 \mathrm{mM}$ sulfuric acid, flowing at $0.75 \mathrm{~mL} / \mathrm{min}$.

\section{Results}

\subsection{Pretreatments of Napier Grass}

Prior to hydrolysis of Napier grass by enzyme or using it in fermentation, pretreatment of the grass is necessary in order to obtain biomass that is more vulnerable to further hydrolysis. Investigations in using alkali, acid and their combinations in pretreatment of Napier grass were carried out to determine for suitable conditions when applying each pretreatment regime.

\subsubsection{Alkali Pretreatment}

In order to obtain pretreatment conditions using alkali, $\mathrm{NaOH}$ concentrations ( $A$ in molarity), treatment temperature $\left(B\right.$ in $\left.{ }^{\circ} \mathrm{C}\right)$ and time ( $C$ in min) were varied within the value ranges indicated in Table 1. By using the Box-Behnken design, experimental runs and their respective results were obtained as shown in Table 2. The data fitted well with this following quadratic equation with R-squared value of 0.9843 .

$$
\begin{aligned}
\mathrm{y}=7.24+19.8 A+0.045 B & +0.168 C+0.093 A B+0.015 A C-0.0014 B C-6.46 A^{2} \\
& +0.00081 B^{2}-0.00029 C^{2}
\end{aligned}
$$

Table 2. Experimental runs and results for determining conditions of alkali pretreatment following the Box-Behnken design.

\begin{tabular}{ccccc}
\hline Run No. & $\mathbf{N a O H}, \boldsymbol{A}$ & Temperature, $\boldsymbol{B}$ & Time, $\boldsymbol{C}$ & Susceptibility \\
\hline & $\mathbf{( M )}$ & $\left.\mathbf{(}{ }^{\circ} \mathbf{C}\right)$ & $\mathbf{( m i n )}$ & $\left.\mathbf{( g}_{\text {RS, susceptibility }} \mathbf{L}\right)$ \\
\hline 1 & 3 & 75 & 30 & 24.3 \\
2 & 1.625 & 75 & 105 & 31.7 \\
3 & 0.25 & 75 & 180 & 10.8 \\
4 & 1.625 & 100 & 180 & 35.8 \\
5 & 1.625 & 75 & 105 & 32.4 \\
6 & 1.625 & 75 & 105 & 33.4 \\
7 & 0.25 & 100 & 105 & 10.0 \\
8 & 3 & 100 & 105 & 39.1 \\
9 & 0.25 & 50 & 105 & 9.62 \\
10 & 1.625 & 50 & 180 & 31.2 \\
11 & 1.625 & 75 & 105 & 31.7 \\
12 & 0.25 & 75 & 30 & 9.80 \\
13 & 1.625 & 50 & 30 & 22.4 \\
14 & 1.625 & 100 & 30 & 37.7 \\
15 & 3 & 75 & 180 & 31.4 \\
16 & 3 & 50 & 105 & 26.0 \\
17 & 1.625 & 75 & 105 & 26.0 \\
\hline
\end{tabular}


The analysis of variance (ANOVA) for the model (Table 3, NaOH) indicated that all the factors had a significant effect on the susceptibility of the grass to cellulase hydrolysis. In addition, interactions between $\mathrm{NaOH}$ concentration and temperature $(\mathrm{A}, \mathrm{B})$ and between temperature and time $(\mathrm{B}, \mathrm{C})$ also had significant effects as demonstrated in Figure 1. The plots indicate that an increase in the concentration of $\mathrm{NaOH}$ resulted in an increase in reducing sugar obtained from the susceptibility test until the concentration was approximately $2 \mathrm{M}$; then the sugar started to decrease. Furthermore, the time taken in pretreatment has shown its dependence on the temperature used (Figure 1b). At low pretreatment temperature, the grass was more susceptible to cellulase hydrolysis with longer treatment time whereas time had little effect at high treatment temperature.

Table 3. $P$-values obtained from ANOVA (analysis of variance) for response surface quadratic models used in the prediction of suitable conditions for pretreatments of Napier grass.

\begin{tabular}{ccccc}
\hline Source & $p$-Value & Source & \multicolumn{2}{c}{$p$-Value } \\
\hline & $\mathbf{N a O H}$ & & $\mathbf{H}_{\mathbf{2}} \mathbf{S O}_{\mathbf{4}}$ & $\mathbf{N a O H}+\mathbf{H}_{\mathbf{2}} \mathbf{S O}_{\mathbf{4}}$ \\
\hline Model & $<0.0001$ & Model & 0.0075 & 0.0055 \\
$A-\mathrm{NaOH}$ & $<0.0001$ & $A-\mathrm{H}_{2} \mathrm{SO}_{4}$ & 0.0022 & 0.0244 \\
$B-$ Temperature & 0.0005 & $B-$ Temperature & 0.0011 & 0.0004 \\
$C-$-Time & 0.0318 & $C$-Time & 0.0979 & 0.9906 \\
$A B$ & 0.0145 & $A B$ & 0.2714 & 0.8541 \\
$A C$ & 0.1648 & $A C$ & 0.7242 & 0.5962 \\
$B C$ & 0.0306 & $B C$ & 0.0766 & 0.7019 \\
$A^{2}$ & $<0.0001$ & $A^{2}$ & 0.0923 & 0.0210 \\
$B^{2}$ & 0.6162 & $B^{2}$ & 0.7228 & 0.0061 \\
$C^{2}$ & 0.1380 & $C^{2}$ & 0.1178 & 0.2965 \\
Lack of Fit & 0.1695 & Lack of Fit & 0.5632 & 0.0018 \\
\hline R-Squared & 0.9843 & R-Squared & 0.9053 & 0.9139 \\
Predicted R-Squared & 0.8206 & Predicted R-Squared & 0.3468 & -0.3992 \\
\hline
\end{tabular}

Notes: $\mathrm{NaOH}=$ pretreatment with $\mathrm{NaOH}, \mathrm{H}_{2} \mathrm{SO}_{4}$ = pretreatment with $\mathrm{H}_{2} \mathrm{SO}_{4}$ and $\mathrm{NaOH}+\mathrm{H}_{2} \mathrm{SO}_{4}=$ pretreatment with $\mathrm{NaOH}$ followed by $\mathrm{H}_{2} \mathrm{SO}_{4}$.

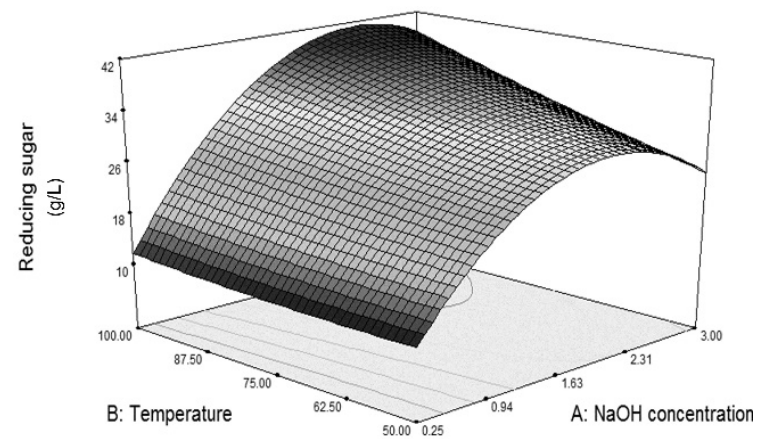

(a)

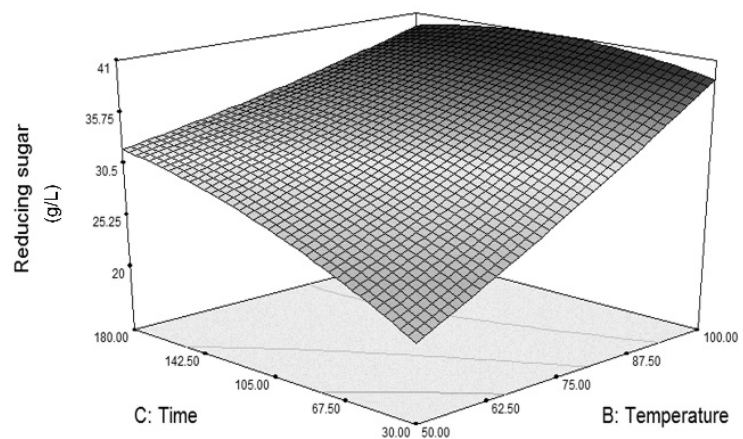

(b)

Figure 1. Surface plots showing significant interactions $(\alpha=0.05)$ between $(\mathbf{a}) \mathrm{NaOH}$ concentration and temperature $(A B)$ at 116 min and $(\mathbf{b})$ temperature and time $(B C)$ at $1.99 \mathrm{M} \mathrm{NaOH}$ in alkali pretreatment on reducing sugar obtained from the susceptibility test.

The equation predicted the pretreatment conditions that resulted in the highest susceptibility (39.3 $\mathrm{g}_{\mathrm{RS}}$, susceptibility/L) of $15 \%$ dried grass to be $1.99 \mathrm{M} \mathrm{NaOH}, 95.7^{\circ} \mathrm{C}$ and $116 \mathrm{~min}$. A verification test using these conditions in pretreating Napier grass resulted in $38.4 \mathrm{~g} / \mathrm{L}$ of reducing sugar obtained from the susceptibility test, which was a $2.2 \%$ deviation from the model prediction. 


\subsubsection{Dilute Acid Pretreatment}

In the investigation for suitable conditions in pretreatment of Napier grass by dilute acid, three factors of interest were $\mathrm{H}_{2} \mathrm{SO}_{4}$ concentration $(A$ in $\% v / v)$, temperature $\left(B\right.$ in $\left.{ }^{\circ} \mathrm{C}\right)$ and time ( $C$ in min). Their levels as indicated in Table 1 was applied to the Box-Behnken design and the results of 17 experimental runs are shown in Table 4. The data were fitted with a quadratic equation. The resulting equation gave the best fit with R-squared value of 0.9053 :

$$
\begin{gathered}
\mathrm{y}=-3.40-1.06 A+0.124 B+ \\
-0.110 C+0.008 A B-0.0011 A C-0.00063 B C+0.130 A^{2} \\
-0.00025 B^{2}-0.00023 C^{2}
\end{gathered}
$$

Table 4. Experimental runs and results for determining conditions of dilute acid pretreatment following the Box-Behnken design.

\begin{tabular}{ccccc}
\hline Run No. & $\mathbf{H}_{\mathbf{2}} \mathbf{S O}_{\mathbf{4}}, \boldsymbol{A}$ & Temperature, $\boldsymbol{B}$ & Time, $\boldsymbol{C}$ & Susceptibility \\
\hline & $\mathbf{( \% )}$ & $\left.\mathbf{(}{ }^{\circ} \mathbf{C}\right)$ & $\mathbf{( m i n )}$ & $\left.\mathbf{( g}_{\text {RS, susceptibility }} / \mathbf{L}\right)$ \\
\hline 1 & 3 & 120 & 120 & 9.57 \\
2 & 3 & 100 & 75 & 9.17 \\
3 & 1 & 100 & 120 & 8.36 \\
4 & 3 & 100 & 75 & 8.02 \\
5 & 5 & 100 & 120 & 9.77 \\
6 & 1 & 80 & 75 & 7.76 \\
7 & 3 & 100 & 75 & 8.62 \\
8 & 3 & 100 & 75 & 9.37 \\
9 & 3 & 80 & 120 & 8.32 \\
10 & 3 & 80 & 30 & 5.95 \\
11 & 5 & 120 & 75 & 11.5 \\
12 & 3 & 120 & 30 & 9.47 \\
13 & 5 & 80 & 75 & 9.13 \\
14 & 1 & 120 & 75 & 8.86 \\
15 & 3 & 100 & 75 & 9.33 \\
16 & 5 & 100 & 30 & 9.73 \\
17 & 1 & 100 & 30 & 7.92 \\
\hline
\end{tabular}

Analysis of variance for the model (Table $3, \mathrm{H}_{2} \mathrm{SO}_{4}$ ) suggested that the main factors that posed significant influence on the susceptibility of the grass to cellulase hydrolysis at $95 \%$ confidence level were $\mathrm{H}_{2} \mathrm{SO}_{4}$ concentration $(A)$ and temperature $(B)$. Time was also significant but at a higher significance level $(\alpha=0.1)$. In pretreatment with dilute acid, interaction between factors did not significantly affect the susceptibility of the grass. Nonetheless, the interaction between time and temperature $(B C)$ was significant at a $90 \%$ confidence level. The surface plot in Figure 2 shows that temperature affected the susceptibility strongly when using a short pretreatment time. Its effect was lesser at longer treatment time. Furthermore, combination of high temperature and long treatment time exerted detrimental effects on the susceptibility of the grass at $5 \% \mathrm{H}_{2} \mathrm{SO}_{4}$.

The quadratic model predicted the maximum reducing sugar from susceptibility test to be $11.6 \mathrm{~g} / \mathrm{L}$. The respective conditions were pretreating the grass at $15 \%$ loading with $5 \% v / v \mathrm{H}_{2} \mathrm{SO}_{4}$ at $120{ }^{\circ} \mathrm{C}$ for $56 \mathrm{~min}$. The verification test resulted in $11.4 \pm 0.1 \mathrm{~g} / \mathrm{L}$ of reducing sugar from susceptibility test. Although the predicted R-squared of this model was low, these results of the conditions were still valid since the conditions were similar to those of run number 11. The small difference in pretreatment time between run number 11 and the predicting value was insignificant, as the pretreatment time did not have a significant effect on the susceptibility test result.

According to the susceptibility results in Table 4, it should be noted that dilute acid pretreatment was generally inferior to alkali pretreatment. Lower reducing sugar released in susceptibility test indicated that the pretreated grass was less susceptible to cellulase hydrolysis. 


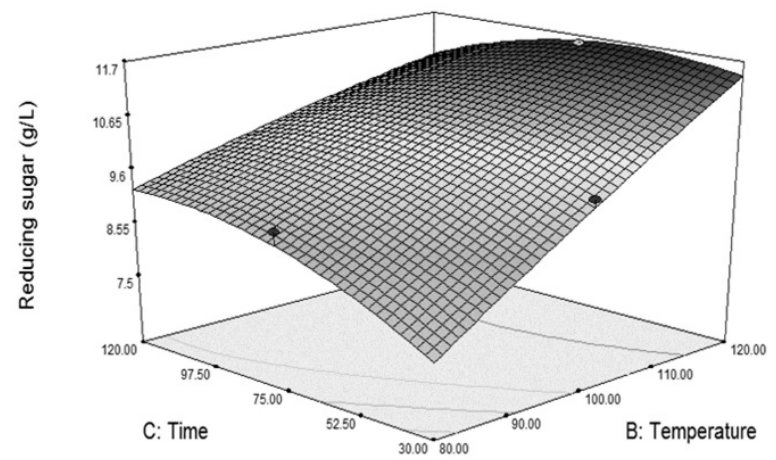

Figure 2. Surface plot showing interactions $(\alpha=0.10)$ between temperature and time $(B C)$ at optimal $\mathrm{H}_{2} \mathrm{SO}_{4}$ concentration $(5 \% \mathrm{v} / \mathrm{v})$ in dilute acid pretreatment on reducing sugar obtained from the susceptibility test.

\subsubsection{Alkali Followed by Acid Pretreatment}

In this pretreatment, Napier grass was firstly pretreated with $\mathrm{NaOH}$ under the best conditions. The $\mathrm{NaOH}$-treated grass was subjected to the treatment using the same factors as in the dilute acid pretreatment but the levels were adjusted as shown in Table 1 . The results from all 17 experimental runs showed that the difference between the lowest and highest values of reducing sugars from susceptibility test was quite narrow (Table 5). This circumstance indicated the more profound effect of alkali pretreatment on the biomass such that further treatment by acid resulted in small changes in susceptibility values.

Table 5. Experimental runs and results for determining conditions of alkali followed by dilute acid pretreatments following the Box-Behnken design.

\begin{tabular}{ccccc}
\hline Run No. & $\mathbf{H}_{\mathbf{2}} \mathbf{S O}_{\mathbf{4}} \boldsymbol{A}$ & Temperature, $\boldsymbol{B}$ & Time, $\boldsymbol{C}$ & Susceptibility \\
\hline & $\mathbf{( \% )}$ & $\left({ }^{\circ} \mathbf{C}\right)$ & $\mathbf{( m i n )}$ & $\left(\mathbf{g}_{\text {RS, susceptibility }} / \mathbf{L}\right)$ \\
\hline 1 & 5 & 75 & 180 & 29.5 \\
2 & 1 & 75 & 180 & 33.9 \\
3 & 5 & 100 & 120 & 23.7 \\
4 & 1 & 50 & 120 & 30.7 \\
5 & 5 & 75 & 60 & 28.1 \\
6 & 3 & 50 & 60 & 34.3 \\
7 & 1 & 100 & 120 & 25.8 \\
8 & 5 & 50 & 120 & 29.2 \\
9 & 1 & 75 & 60 & 31.1 \\
10 & 3 & 75 & 120 & 32.0 \\
11 & 3 & 50 & 180 & 32.7 \\
12 & 3 & 100 & 180 & 25.2 \\
13 & 3 & 75 & 120 & 32.3 \\
14 & 3 & 75 & 120 & 31.8 \\
15 & 3 & 75 & 120 & 31.5 \\
16 & 3 & 75 & 120 & 31.6 \\
17 & 3 & 100 & 60 & 27.9 \\
\hline
\end{tabular}

Analysis of variance (Table $3, \mathrm{NaOH}+\mathrm{H}_{2} \mathrm{SO}_{4}$ ) suggested that acid concentration and temperature were the two factors that influenced the susceptibility of the grass to cellulase hydrolysis at $97.6 \%$ and more than $99.9 \%$ confidence levels, respectively. The ANOVA also indicated that there was no interaction between factors. 
The experimental data was fitted to a quadratic model with the resulting equation:

$$
\begin{gathered}
\mathrm{y}=15.2+2.82 A+0.522 B-0.027 C-0.0026 A B-0.0031 A C-0.00018 B C-0.490 A^{2} \\
-0.0041 B^{2}+0.00021 C^{2}
\end{gathered}
$$

This equation fitted well with the experimental data with R-squared value of 0.9139 . The model predicted the best conditions that yielded the highest susceptibility of $33.5 \mathrm{~g}_{\mathrm{RS} \text {,susceptibility }} / \mathrm{L}$ to be the use of $2.53 \% v / v \mathrm{H}_{2} \mathrm{SO}_{4}$ at $62{ }^{\circ} \mathrm{C}$ for $60 \mathrm{~min}$ at $15 \%$ grass loading. Although the lack of fit test was shown as significant ( $p$-value $=0.0018$ ) and the predicted $\mathrm{R}$-squared was negative, the result of the independent susceptibility test using the predicted conditions $\left(33.0 \pm 0.5 \mathrm{~g}_{\mathrm{RS} \text {, susceptibility }} / \mathrm{L}\right)$ was very close to the predicted value. This situation was possible regardless of the significant lack of fit and due to the following supporting reason. Since the time was not a significant factor and there was no interaction between factors, it would not affect the response. Considering runs with the same temperature, the optimum values of acid concentration $(2.53 \% v / v)$ laid between run 9 and 10 (Table 5) where the temperature was $75^{\circ} \mathrm{C}$. The responses of the two runs were very similar at 31.6

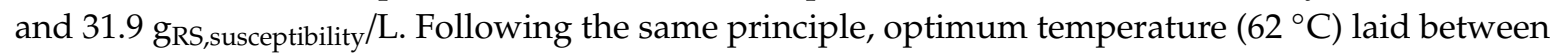
values in run 10 and 11 (Table 5) where acid concentration was the same. The responses of the 2 runs were also similar at 31.9 and $33.3 \mathrm{~g}_{\mathrm{RS} \text {,susceptibility }} / \mathrm{L}$. From these explanations, it was evident that changes in acid concentration and temperature between those ranges barely affected the responses. Therefore, the confirmation test using the predicted conditions was valid. However, low predicted $\mathrm{R}$-squared values indicated that this equation is not suitable for predicting the response of the conditions that were not at the experimental points.

\subsection{Physical Structure and Composition of Napier Grass after Pretreatments}

Napier grass obtained after the three pretreatment regimes were analyzed for their physical structures and structural compositions. The results in Table 6 demonstrated that all pretreatments are able to reduce the amount of lignin in Napier grass, although at different capability. Reduction in lignin content was more pronounced when treating with $\mathrm{NaOH}$ than using the acid. The acid directly affects the hemicellulose part of the grass as reflected in the more than $50 \%$ reduction in hemicellulose in the pretreated samples. $\mathrm{NaOH}$ also dissolves some hemicellulose causing a drop in hemicellulose content, although not to the same extent caused by the dilute acid. As the results of pretreatment, an increase in the cellulose fraction was evident.

\begin{tabular}{|c|c|c|c|c|}
\hline Composition & Native Grass & $\begin{array}{c}\text { Treated Grass } \\
\text { with } \mathrm{NaOH}\end{array}$ & $\begin{array}{c}\text { Treated Grass } \\
\text { with } \mathrm{H}_{2} \mathrm{SO}_{4}\end{array}$ & $\begin{array}{l}\text { Treated Grass with } \\
\left(\mathrm{NaOH}+\mathrm{H}_{2} \mathrm{SO}_{4}\right)\end{array}$ \\
\hline \% Lignin & $19.4 \pm 0.1^{\mathrm{a}}$ & $9.90 \pm 0.4^{\mathrm{c}}$ & $15.0 \pm 0.6^{\mathrm{b}}$ & $4.27 \pm 0.34^{\mathrm{d}}$ \\
\hline \% Cellulose & $35.2 \pm 1.2^{b}$ & $46.5 \pm 0.6^{\mathrm{a}}$ & $46.6 \pm 0.0^{\mathrm{a}}$ & $48.3 \pm 1.7^{\mathrm{a}}$ \\
\hline$\%$ Hemicellulose & $18.1 \pm 0.3^{a}$ & $14.0 \pm 0.2^{b}$ & $7.72 \pm 0.0^{\mathrm{c}}$ & $13.9 \pm 0.2^{b}$ \\
\hline$\%$ Ash & $1.73 \pm 0.18^{a}$ & $0.58 \pm 0.03^{c}$ & $0.98 \pm 0.08^{b}$ & $0.25 \pm 0.07^{\mathrm{d}}$ \\
\hline $\begin{array}{c}\text { Susceptibility } \\
\left.\text { ( } g_{R S} \text {, susceptibility } / L\right)\end{array}$ & $\mathrm{n} / \mathrm{a}$ & $38.4 \pm 0.14^{\mathrm{a}}$ & $11.4 \pm 0.1^{\mathrm{c}}$ & $33.0 \pm 0.5^{b}$ \\
\hline
\end{tabular}

Table 6. Structural composition of native and pretreated Napier grasses.

Notes: (1) The statistical comparisons were between the same compositions of the different treatments. The same letter indicated that the values were not significantly different at $95 \%$ confidence level. (2) All samples were extractive-free. $\mathrm{n} / \mathrm{a}=$ not available.

When matching the susceptibility data to the structural composition of the pretreated grasses, it is evident that the presence of lignin relates to a much lesser vulnerability of the biomass to hydrolysis by cellulase. Although the pretreated grasses have similar polysaccharide contents, they do not result in the same level of hydrolysis as indicated by the resulting reducing sugar from the susceptibility test.

Surfaces of native grass observed under SEM shows smooth and packed-layer surface (Figure 3a). The layering surface still exists but with loose, wrinkled, and swelling appearance after the pretreatment 
with $\mathrm{NaOH}$, both with and without acid pretreatment (Figure 3b,d). A different effect when using acid pretreatment is observed such that the grass appeared fibrous with signs of degradation but the appearance is still packed (Figure 3c).

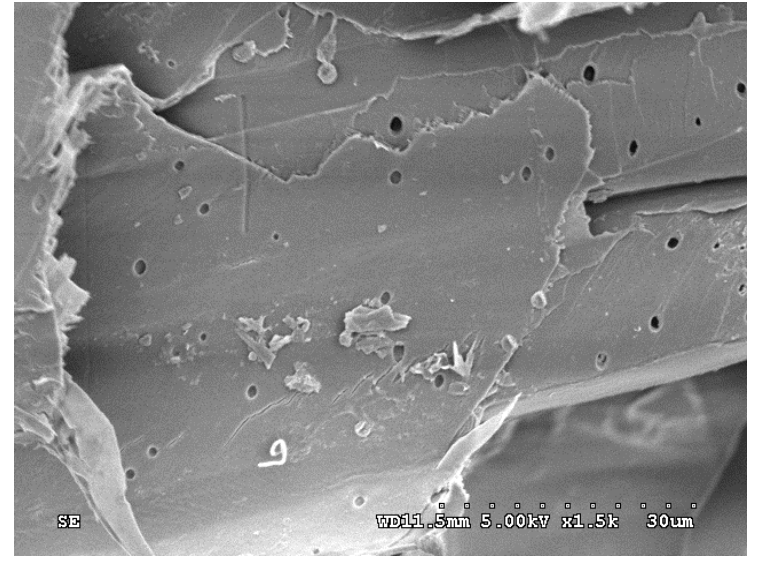

(a)

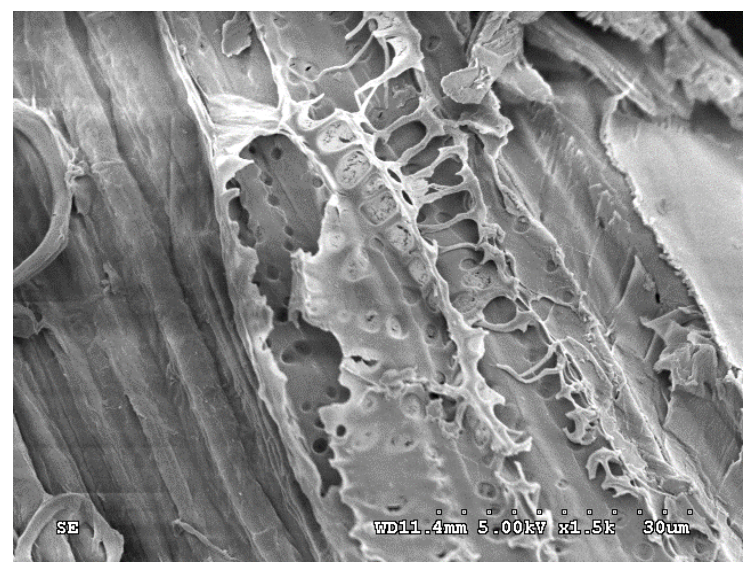

(c)

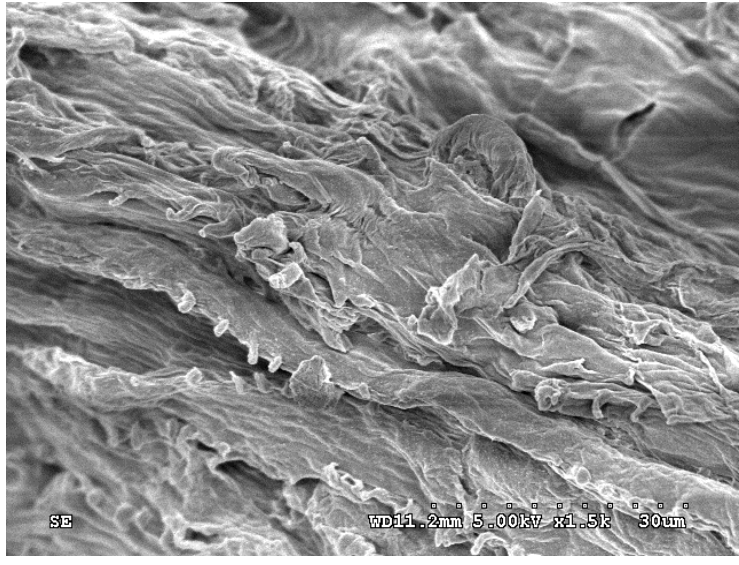

(b)

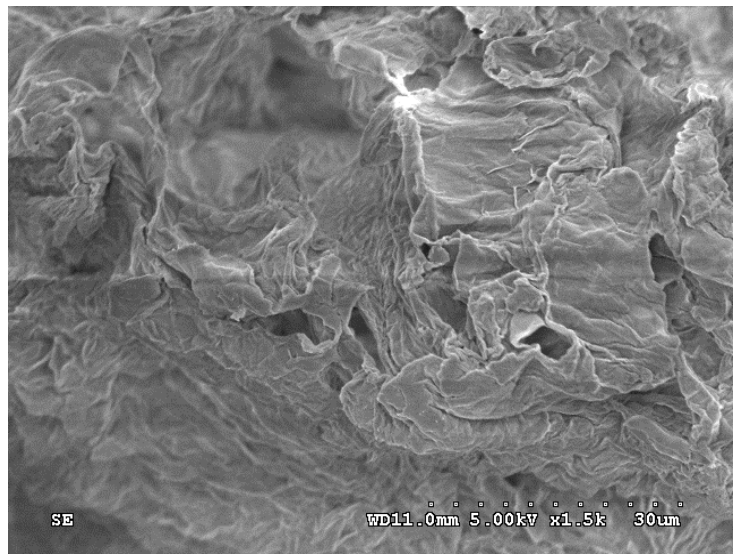

(d)

Figure 3. Physical appearances of Napier grass (a) in native form, (b) when pretreated with $\mathrm{NaOH}$, (c) when pretreated with $\mathrm{H}_{2} \mathrm{SO}_{4}$ and (d) pretreated with $\mathrm{NaOH}$ followed by $\mathrm{H}_{2} \mathrm{SO}_{4}$ under a scanning electron microscope at $1500 \times$ magnification.

According to the results on susceptibility to cellulase hydrolysis, the structural compositions and the physical structures of the grass, we conclude that the pretreatment of $15 \%$ dried grass by $1.99 \mathrm{M}$ $\mathrm{NaOH}$ at $95.7^{\circ} \mathrm{C}$ for $116 \mathrm{~min}$ is suitable as it makes the grass most susceptible to further enzymatic hydrolysis. The treatment with dilute acid following the $\mathrm{NaOH}$ pretreatment is not necessary, as the susceptibility did not improve with the extra treatment.

\subsection{Enzymatic Hydrolysis of Pretreated Grass}

Although the previous results on pretreatment methods have suggested the use of $\mathrm{NaOH}$ alone in pretreating the Napier grass, we decided to investigate the enzymatic hydrolysis of the grass from all three pretreatment methods. Pretreated grasses were dried prior to the hydrolysis. The hydrolysis conditions followed those shown in Table 1. The reducing sugar concentration in the liquid hydrolysate was the response used for the analysis of the results and the prediction of the suitable hydrolysis conditions.

The experimental results of enzymatic hydrolysis of grass pretreated with the three methods were demonstrated in Table 7. In general, both pretreatments involving $\mathrm{NaOH}$ resulted in similar 
reducing sugar concentrations and the values were significantly higher than that treated with dilute acid. The ANOVA of the results in Table 8 show that all factors (enzyme dosage, hydrolysis time, and substrate loading) affect the amount of sugar obtained in the liquid hydrolysate, except for the grass pretreated with $\mathrm{H}_{2} \mathrm{SO}_{4}$ where enzyme dosage does not affect the reducing sugar obtained.

Table 7. Experimental runs based on the Box-Behnken design and results for determining conditions of enzymatic hydrolysis of pretreated Napier grass.

\begin{tabular}{ccccccc}
\hline Run & Enzyme, $\boldsymbol{A}$ & Time, $\boldsymbol{B}$ & Substrate Loading, $\boldsymbol{C}$ & \multicolumn{3}{c}{ Reducing Sugars $\mathbf{( g / L )}$} \\
\hline & $\mathbf{( F P U / g )}$ & $\mathbf{( h )}$ & $\mathbf{( \% )}$ & $\mathbf{N a O H}$ & $\mathbf{H}_{\mathbf{2}} \mathbf{S O}_{\mathbf{4}}$ & $\mathbf{N a O H}_{\mathbf{H}} \mathbf{H}_{\mathbf{2}} \mathbf{S O}_{\mathbf{4}}$ \\
\hline 1 & 30 & 120 & 5 & 65.5 & 19.3 & 57.1 \\
2 & 30 & 72 & 10 & 83.6 & 33.4 & 99.9 \\
3 & 50 & 120 & 10 & 98.9 & 36.1 & 112.5 \\
4 & 10 & 120 & 10 & 71.6 & 32.5 & 89.5 \\
5 & 30 & 24 & 5 & 53.2 & 11.6 & 50.9 \\
6 & 10 & 72 & 5 & 43.3 & 9.85 & 46.6 \\
7 & 30 & 72 & 10 & 83.0 & 32.3 & 98.2 \\
8 & 10 & 72 & 15 & 56.9 & 52.1 & 75.9 \\
9 & 10 & 24 & 10 & 50.3 & 18.8 & 82.9 \\
10 & 30 & 72 & 15 & 84.5 & 32.8 & 98.1 \\
11 & 30 & 120 & 10 & 128.6 & 54.5 & 125.7 \\
12 & 50 & 72 & 10 & 28.7 & 23.2 & 73.1 \\
13 & 30 & 72 & 10 & 84.2 & 33.7 & 98.2 \\
14 & 50 & 24 & 15 & 57.5 & 15.3 & 74.9 \\
15 & 30 & 72 & 15 & 83.2 & 34.2 & 99.9 \\
16 & 50 & 72 & 24 & 81.6 & 31.0 & 107.3 \\
17 & 30 & & & &
\end{tabular}

Table 8. ANOVA for response surface quadratic models used in prediction of suitable conditions for enzyme hydrolysis of pretreated Napier grass.

\begin{tabular}{cccc}
\hline Source & \multicolumn{3}{c}{$p$-Value } \\
\cline { 2 - 4 } & $\mathbf{N a O H}$ & $\mathbf{H}_{\mathbf{2}} \mathbf{S O}_{\mathbf{4}}$ & $\mathbf{N a O H}+\mathbf{H}_{\mathbf{2}} \mathbf{S O}_{\mathbf{4}}$ \\
\hline Model & $<0.0001$ & $<0.0001$ & $<0.0001$ \\
$A$-Enzyme dosage & $<0.0001$ & 0.7787 & $<0.0001$ \\
$B$-Time & $<0.0001$ & $<0.0001$ & $<0.0001$ \\
$C$-Substrate loading & $<0.0001$ & $<0.0001$ & $<0.0001$ \\
$A B$ & $<0.0001$ & 0.0009 & $<0.0001$ \\
$A C$ & $<0.0001$ & $<0.0001$ & $<0.0001$ \\
$B C$ & $<0.0001$ & $<0.0001$ & $<0.0001$ \\
$A^{2}$ & $<0.0001$ & $<0.0001$ & 0.0100 \\
$B^{2}$ & $<0.0001$ & $<0.0001$ & $<0.0001$ \\
$C^{2}$ & $<0.0001$ & 0.0789 & $<0.0001$ \\
Lack of Fit & 0.0904 & 0.7141 & 0.2125 \\
R-Squared & 0.9993 & 0.9989 & 0.9987 \\
Predicted R-Squared & 0.9910 & 0.9939 & 0.9865
\end{tabular}

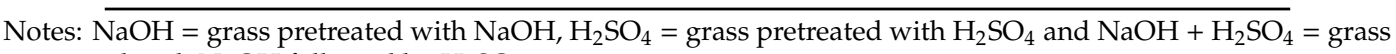
pretreated with $\mathrm{NaOH}$ followed by $\mathrm{H}_{2} \mathrm{SO}_{4}$.

Quadratic equations for predicting the suitable hydrolysis conditions for the pretreated grass using different pretreatment regimes are as follows:

Grass pretreated with $\mathrm{NaOH}$ :

$$
\begin{aligned}
\mathrm{y}=34.32+1.12 A-0.459 B+ & 1.47 C+0.0052 A B+0.170 A C+0.036 B C-0.046 A^{2} \\
& +0.0018 B^{2}-0.224 C^{2}
\end{aligned}
$$


Grass pretreated with $\mathrm{H}_{2} \mathrm{SO}_{4}$ :

$$
\begin{aligned}
\mathrm{y}=-25.60+1.01 A+0.221 B+ & 3.07 C+0.0018 A B-0.068 A C+0.018 B C-0.0077 A^{2} \\
& +0.0019 B^{2}-0.026 C^{2}
\end{aligned}
$$

Grass pretreated with $\mathrm{H}_{2} \mathrm{SO}_{4}$ followed by $\mathrm{NaOH}$ :

$$
\begin{gathered}
\mathrm{y}=-29.77+0.879 A-0.131 B+14.59 C+0.0081 A B-0.096 A C+0.027 B C-0.0052 A^{2} \\
-0.0030 B^{2}-0.409 C^{2}
\end{gathered}
$$

where $\mathrm{y}=$ reducing sugar $(\mathrm{g} / \mathrm{L}), A=$ enzyme dosage (FPU/g), $B=$ hydrolysis time $(\mathrm{h})$ and $C=$ substrate loading $(\% w / v)$. All model equations have high R-squared values, which indicate that the models fit well with the experimental data. In addition, the high values of predicted R-squared suggest that the model equations can be used to predict the reducing sugar obtained from the hydrolysis.

The surface plots in Figure 4 show the reducing sugar concentrations obtained from varying enzyme dosages and times when hydrolyzing grasses from different pretreatments. Hydrolysis time greatly affects the sugar obtained, such that longer time results in higher sugar concentration. By observing the surface shapes, the pretreatment involving the dilute acid causes a different response pattern of sugar obtained from hydrolysis when compared with the pretreatment with $\mathrm{NaOH}$ alone. Pretreating the grass with dilute acid seems to gain some benefit from the use of lower enzyme dosage with a long hydrolysis time, as shown in Figure $4 \mathrm{~b}$,c. While removing lignin by $\mathrm{NaOH}$ could loosen the grass structure and allow for more cellulase accessibility to the cellulose, dissolving hemicellulose by dilute acid could also increase the cellulose accessibility [24]. Since the cellulose accessibility is the major factor on cellulase hydrolysis [12,13], the extra increase in this accessibility allows better penetration of the enzyme during hydrolysis even at a lower enzyme dosage.

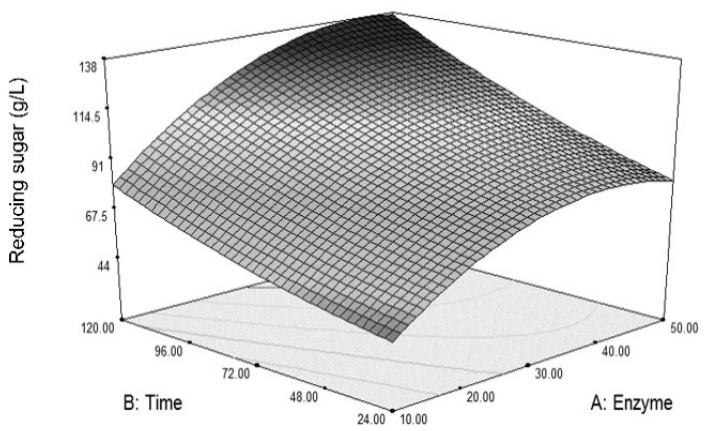

(a)

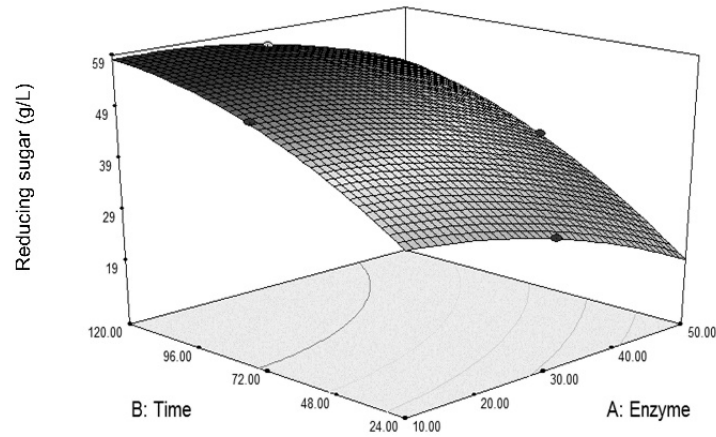

(b)

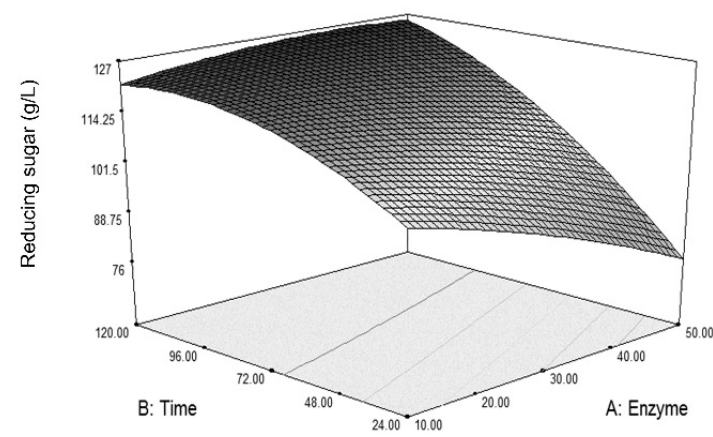

(c)

Figure 4. Surface plots showing significant interactions $(\alpha=0.05)$ between enzyme dosage and time $(A B)$ for the enzymatic hydrolysis of Napier grass (a) pretreated with $\mathrm{NaOH},(\mathbf{b})$ pretreated with $\mathrm{H}_{2} \mathrm{SO}_{4}$, and (c) pretreated with $\mathrm{NaOH}$ followed by $\mathrm{H}_{2} \mathrm{SO}_{4}$, each at their optimal conditions. 
The hydrolysis conditions obtained from the model equations for pretreated grasses of different pretreatment regimes are shown in Table 9, together with the predicted and actual reducing sugar concentrations obtained from the hydrolysis. Pretreatment solely with $\mathrm{NaOH}$ resulted in the highest reducing sugar concentrations when the pretreated grass was hydrolyzed with cellulase. Confirmation tests using the predicted optimal conditions were carried out for all pretreated grasses and the reducing sugar concentrations were very close to the predicting values.

Table 9. Optimal values of operating conditions for enzymatic hydrolysis and reducing sugar obtained.

\begin{tabular}{ccccccc}
\hline & \multicolumn{2}{c}{$\mathbf{N a O H}$} & \multicolumn{2}{c}{$\mathbf{H}_{\mathbf{2}} \mathbf{S O}_{4}$} & \multicolumn{2}{c}{$\mathbf{N a O H}+\mathbf{H}_{2} \mathbf{S O}_{4}$} \\
\cline { 2 - 6 } & $\begin{array}{c}\text { Optimal } \\
\text { Values }\end{array}$ & Sugar (g/L) & $\begin{array}{c}\text { Optimal } \\
\text { Values }\end{array}$ & Sugar (g/L) & $\begin{array}{c}\text { Optimal } \\
\text { Values }\end{array}$ & Sugar (g/L) \\
\hline $\begin{array}{c}\text { Enzyme dosage } \\
\text { (FPU/g) }\end{array}$ & 40 & & 11 & & 33.6 & \\
$\quad \begin{array}{c}\text { Time } \\
(\mathrm{h})\end{array}$ & 117 & $\begin{array}{c}140.5 \\
(139.7 \pm 0.8)\end{array}$ & 105 & 57.3 & 119.2 & 125.8 \\
$\begin{array}{c}\text { Substrate loading } \\
(\% w / v)\end{array}$ & 15 & & 14.8 & & 14.9 & \\
\hline
\end{tabular}

Note: Sugar concentrations are reducing sugar. Values are the predicted concentration from model equations. Values in parentheses are from confirmation tests.

According to the results, cellulase hydrolysis of Napier grass pretreated with $\mathrm{NaOH}$ and with $\mathrm{NaOH}$ followed by $\mathrm{H}_{2} \mathrm{SO}_{4}$ resulted in similar reducing sugar concentrations, with the slightly higher concentration in the pretreatment with $\mathrm{NaOH}$. The sugar concentrations obtained from the $\mathrm{NaOH}$-pretreated grasses were high and in accordance with the polysaccharide contents in the pretreated grasses. However, the amount of sugar obtained from the acid-pretreated grass was much lower, regardless of the similar polysaccharide contents. These results emphasized the importance of cellulase susceptibility of the biomass on the hydrolysis rather than the polysaccharide contents of the biomass.

Both regimes involving the use of $\mathrm{NaOH}$ in pretreatment could be used for preparing liquid hydrolysates for fermentations due to the high sugar concentrations obtained. However, based on the number of steps involved and the higher sugar concentration obtained, we chose to pretreat the Napier grass in a single step with $\mathrm{NaOH}$ followed by cellulase hydrolysis to prepare the hydrolysate as a substrate for ethanol fermentation. To pretreat the Napier grass, $15 \%$ dried grass is to be soaked in $1.99 \mathrm{M} \mathrm{NaOH}$ and subjects to wet heat at $95.7^{\circ} \mathrm{C}$ for $116 \mathrm{~min}$. Dried pretreated grass is hydrolyzed using cellulase (Cellic ${ }^{\circledR} \mathrm{CTec} 2$ ) at $40 \mathrm{FPU} / \mathrm{g}$ for $117 \mathrm{~h}$ and the grass loading of $15 \%$.

\subsection{Ethanol Production Potentials of Napier Grass}

In evaluating the ethanol production potential, we employed two yeast strains, which are S. cerevisiae TISTR 5339 and S. shehatae ATCC 22984, and two fermentation techniques viz. SHF (separate hydrolysis and fermentation) and SSF (simultaneous saccharification and fermentation). The SHF technique utilizes liquid hydrolysate obtained from enzymatic hydrolysis of $\mathrm{NaOH}$-pretreated Napier grass, while the SSF technique uses the $\mathrm{NaOH}$-pretreated grass in the fermentation.

\subsubsection{Ethanol Production by S. cerevisiae TISTR 5339}

Ethanol production by S. cerevisiae was carried out using two cultivation techniques, SHF and SSF. The liquid hydrolysate used in SHF contained $134.9 \mathrm{~g} / \mathrm{L}$ reducing sugar, of which $90.8 \mathrm{~g} / \mathrm{L}$ was glucose and $18.8 \mathrm{~g} / \mathrm{L}$ was xylose. In SHF (Figure $5 \mathrm{a}$ ), the maximum ethanol of $44.7 \mathrm{~g} / \mathrm{L}$ was obtained after $24 \mathrm{~h}$ cultivation. Glucose utilization was in accord with increasing ethanol concentration. Yeast growth also related to glucose utilization with the maximum specific growth rate of $2.79 \pm 0.09 \mathrm{1} / \mathrm{d}$. The growth ceased when glucose consumption ended. In addition, xylose decreased throughout the fermentation with the total xylose uptake of $6.71 \mathrm{~g} / \mathrm{L}$, which was $32.9 \%$ of the total amount. Slight increase of xylitol 
was observed with the final concentration of $2.47 \mathrm{~g} / \mathrm{L}$. The fermentation profiles suggested that ethanol was mainly produced from glucose with the yield of $0.49 \mathrm{~g} / \mathrm{g}$.

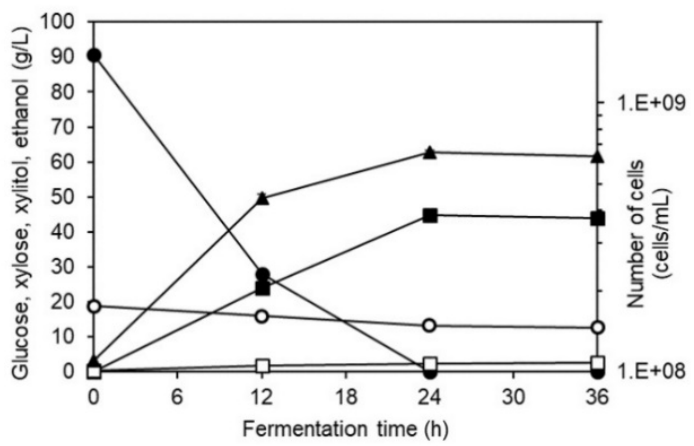

(a)

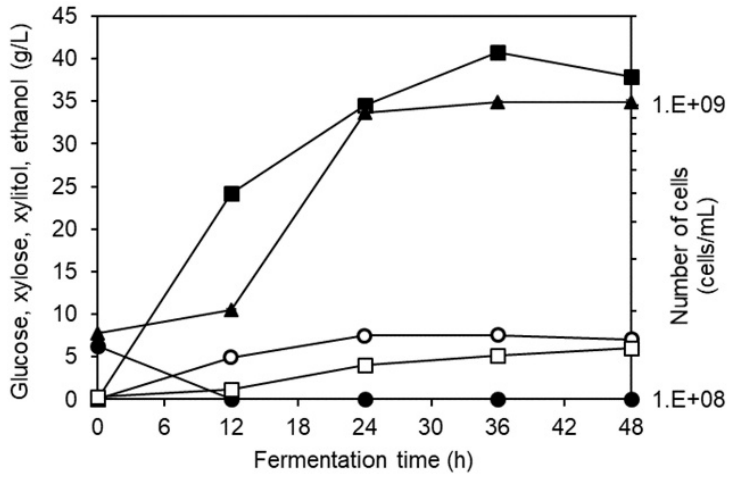

(b)

Figure 5. Fermentation profiles of S. cerevisiae TISTR 5339 when cultivated in (a) liquid hydrolysate of $\mathrm{NaOH}$-pretreated Napier grass using SHF and (b) NaOH-pretreated grass using SSF. Symbols:

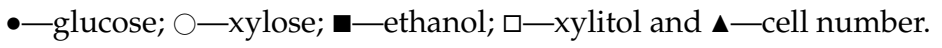

In ethanol production using SSF by S. cerevisiae TISTR 5339 (Figure 5b), glucose remained at a low level throughout the fermentation. Glucose was gradually released and taken up by the yeast to produce ethanol and $40.8 \mathrm{~g} / \mathrm{L}$ of ethanol was produced after $36 \mathrm{~h}$. Yeast growth appeared to be very slow at the beginning of the fermentation. The use of high solid loading in the fermentation could result in this initial apparent slow growth where clear separation of the solid and liquid phases was evident. The growing yeast could attach to the surface of the grass and undetected in the liquid phase. After $12 \mathrm{~h}$, the physical appearance of the fermentation became slurry and the cells could detach from the grass into the liquid resulting in an increase in cell count. The maximum specific growth rate of $3.08 \pm 0.031 / \mathrm{d}$ was slightly higher than that of SHF and the final cell count was slightly higher than that in SHF. Xylose accumulated during the first $24 \mathrm{~h}$ together with xylitol accumulation. The final xylitol concentration was $5.96 \mathrm{~g} / \mathrm{L}$. The simultaneous increase of xylose and xylitol indicated that xylitol was produced along with the release of xylose from the grass.

\subsubsection{Ethanol Production by S. shehatae ATTC 22984}

Both SHF and SSF were also employed in the study of ethanol production by S. shehatae ATTC 22984 (Figure 6a,b). The sugar concentrations in the Napier grass hydrolysate was similar to those used in the SHF study using S. cerevisiae. In SHF, production of ethanol directly related to glucose utilization with the highest concentration of $31.3 \mathrm{~g} / \mathrm{L}$, which was significantly lower than that obtained using S. cerevisiae. Xylose utilization observed during the fermentation was as expected as the yeast is a xylose-fermenting yeast. However, profile analysis suggested that xylose did not contribute to ethanol production but to xylitol production with the final xylitol concentration of $2.5 \mathrm{~g} / \mathrm{L}$. The growth profile in SHF showed the continuous growth during the first $48 \mathrm{~h}$ of fermentation. The uncoupling ethanol production after $48 \mathrm{~h}$ suggested a possibility of product inhibition effect on growth of $S$. shehatae.

When cultivating $S$. shehatae using SSF (Figure $6 \mathrm{~b}$ ), the growth profile in relation to ethanol profile was similar to that occurred in SHF, suggesting also a possibility of growth inhibition by ethanol. The glucose profile showed a slight increase in concentration during the first $24 \mathrm{~h}$ before dropped and remained at low level throughout the fermentation. The small accumulation of glucose suggested a lower growth rate of the yeast as compared to the rate of sugar released from the grass by the action of enzyme. Accumulation of xylose confirmed the ineffective xylose utilization, especially at high ethanol concentration. The final ethanol concentration obtained from SSF was $34 \mathrm{~g} / \mathrm{L}$, which was significantly 
higher than that obtained from SHF. Along with ethanol production, xylitol was also produced and the final concentration was $3.33 \mathrm{~g} / \mathrm{L}$.

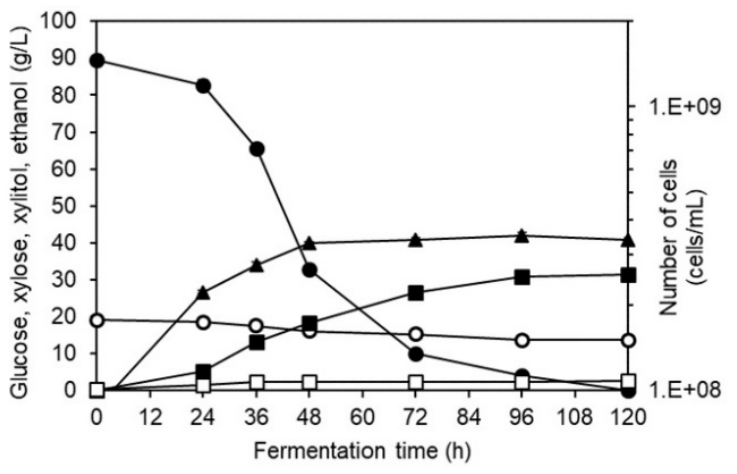

(a)

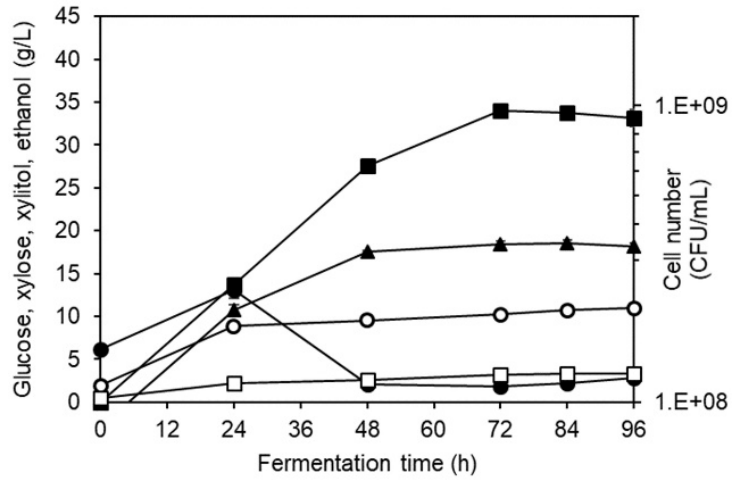

(b)

Figure 6. Fermentation profiles of $S$. shehatae when cultivated in (a) liquid hydrolysate of $\mathrm{NaOH}$-pretreated Napier grass using SHF and (b) $\mathrm{NaOH}$-pretreated grass using SSF. Symbols:

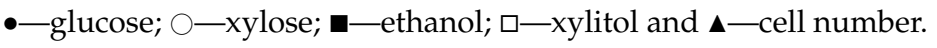

The summary in Table 10 shows that S. cerevisiae TISTR 5339 is able to deliver a superior ethanol production than S. shehatae ATCC 22984, in terms of concentration, productivity, and ethanol yield. S. shehatae, a xylose-fermenting yeast, did not deliver the expected xylose-fermenting ability when fermenting in hydrolysate that contained high glucose concentration. The overall ethanol production yield from Napier grass suggested that the grass could be used for ethanol production with the best yield of $187.4 \mathrm{~g} / \mathrm{kg}$ of dried Napier grass obtained with SHF fermentation by S. cerevisiae. The results of this study are in the range, or above the average, of other studies both in terms of concentration obtained during fermentation and in terms of ethanol yield based on the amount of biomass used (Table 11).

Table 10. Summary on ethanol production from pretreated Napier grass using SSF and hydrolysate of the pretreated grass using SHF by S. cerevisiae and S. shehatae.

\begin{tabular}{ccccc}
\hline \multirow{2}{*}{ Parameters } & \multicolumn{1}{c}{$\begin{array}{c}\text { S. cerevisiae } \\
\text { TISTR 5339 }\end{array}$} & \multicolumn{3}{c}{$\begin{array}{c}\text { S. shehatae } \\
\text { ATCC 22984 }\end{array}$} \\
\cline { 2 - 5 } & SHF & SSF & SHF & SSF \\
\cline { 2 - 5 } & $2.79 \pm 0.09^{\mathrm{b}}$ & $3.08 \pm 0.03^{\mathrm{a}}$ & $0.94 \pm 0.05^{\mathrm{a}}$ & $0.91 \pm 0.03^{\mathrm{a}}$ \\
$\mu_{\max }(\mathrm{l} /$ day) & $44.7 \pm 0.4^{\mathrm{a}}$ & $40.8 \pm 0.8^{\mathrm{b}}$ & $31.3 \pm 0.6^{\mathrm{b}}$ & $34.0 \pm 0.6^{\mathrm{a}}$ \\
$\mathrm{Q}_{\mathrm{p}, \text { fermentation }(\mathrm{g} / \mathrm{L} . \mathrm{h})}$ & $1.87 \pm 0.02^{\mathrm{a}}$ & $1.14 \pm 0.02^{\mathrm{b}}$ & $0.26 \pm 0.01^{\mathrm{b}}$ & $0.47 \pm 0.01^{\mathrm{a}}$ \\
$\mathrm{Q}_{\mathrm{p}, \text { overall process }}$ (g/L.h) & $0.31 \pm 0.00^{\mathrm{b}}$ & $1.14 \pm 0.02^{\mathrm{a}}$ & $0.13 \pm 0.00^{\mathrm{b}}$ & $0.47 \pm 0.01^{\mathrm{a}}$ \\
$\mathrm{Y}_{\mathrm{ps}}$ (mg/g treated grass) & $298.0 \pm 0.0^{\mathrm{a}}$ & $272.0 \pm 0.0^{\mathrm{b}}$ & $208.7 \pm 0.0^{\mathrm{b}}$ & $227.3 \pm 0.0^{\mathrm{a}}$ \\
$\mathrm{Y}_{\mathrm{ps}}$ (mg/g grass) & $187.4 \pm 0.0^{\mathrm{a}}$ & $171.1 \pm 0.0^{\mathrm{b}}$ & $131.2 \pm 0.0^{\mathrm{b}}$ & $142.6 \pm 0.0^{\mathrm{a}}$ \\
\hline
\end{tabular}

Notes: (1) $Q_{p}$, fermentation calculation is based only on fermentation time. (2) $Q_{p}$, overall process calculation includes hydrolysate preparation time (5 days) and fermentation time. (3) Comparisons are between different fermentation methods and yeast strains within the same parameter. The same letter indicated that the values were not significantly different at $95 \%$ confidence level. (4) $\mathrm{Y}_{\mathrm{ps}}\left(\mathrm{mg} / \mathrm{g}\right.$ treated grass) $=$ ethanol yield based on pretreated grass (5) $\mathrm{Y}_{\mathrm{ps}}(\mathrm{mg} / \mathrm{g}$ grass $)=$ ethanol yield based on non-pretreated grass.

\section{Discussion}

Regarding the use of dilute acid or $\mathrm{NaOH}$ for pretreatment of Napier or elephant grass, the results varied among several studies but they were all towards the same trend. A study showed that dilute acid reduced both lignin and hemicellulose contents of the grass, while $\mathrm{NaOH}$ treatment only reduced lignin content but not hemicellulose [14]. Our results on dilute acid pretreatment followed a similar reduction trend of both lignin and hemicellulose. However, we found that $\mathrm{NaOH}$ solubilized not only 
lignin, but also the hemicellulose fraction (Table 6). These results agreed with some other studies where hemicellulose reduction was reported in alkali treatment but to a smaller extent when compared to acid pretreatment $[20,24]$. Both lignin and hemicellulose removals by alkali pretreatment were also evident in other biomass, such as sweet sorghum straw [25] and sugarcane bagasse [26].

Table 11. Comparison of ethanol production from Napier grass in various studies.

\begin{tabular}{|c|c|c|c|}
\hline $\begin{array}{c}\text { Microorganism } \\
\text { (Mode of Fermentation) }\end{array}$ & Pretreatment & $\begin{array}{l}\text { Ethanol, g/L } \\
\text { (Yield) }\end{array}$ & References \\
\hline $\begin{array}{l}\text { S. cerevisiae NBRC } 2044 \\
+ \text { E. coli KO11 } \\
\left(\mathrm{SSF}+\mathrm{PF}^{*}\right)\end{array}$ & Low-moisture anhydrous ammonia & $\begin{array}{c}34.2 \mathrm{~g} / \mathrm{L}^{* *} \\
\left(241 \mathrm{mg} / \mathrm{g}^{\#}\right)\end{array}$ & [18] \\
\hline $\begin{array}{l}\text { S. cerevisiae NBRC } 2044 \\
+ \text { E. coli KO11 } \\
\text { (SSCF) }\end{array}$ & Low-moisture anhydrous ammonia & $\begin{array}{c}19.4 \mathrm{~g} / \mathrm{L} \\
(204 \mathrm{mg} / \mathrm{g})\end{array}$ & [17] \\
\hline $\begin{array}{l}\text { Ethanol Red } \\
\text { (SSF) }\end{array}$ & $\mathrm{NaOH}$ & $\begin{array}{c}26.05 \mathrm{~g} / \mathrm{L} \\
(-)\end{array}$ & [14] \\
\hline $\begin{array}{l}\text { S. cerevisiae } \\
\text { (SSF) }\end{array}$ & $\mathrm{H}_{2} \mathrm{SO}_{4}+\mathrm{NaOH}$ & $\begin{array}{c}24 \mathrm{~g} / \mathrm{L} \\
(127.9 \mathrm{mg} \% / \mathrm{g})\end{array}$ & [20] \\
\hline $\begin{array}{c}\text { S. cerevisiae CAT-1 } \\
\text { (SHF) }\end{array}$ & Steam explosion & $\begin{array}{c}\sim 4.5 \mathrm{~g} / \mathrm{L} \\
(87.2 \mathrm{mg} / \mathrm{g})\end{array}$ & {$[21]$} \\
\hline $\begin{array}{l}\text { S. cerevisiae CAT-1 } \\
(\mathrm{SHF})\end{array}$ & Milling + enzyme & $\begin{array}{c}6.1 \mathrm{~g} / \mathrm{L} \\
(-)\end{array}$ & [27] \\
\hline $\begin{array}{l}\text { Z. mobilis + fungi } \\
\text { (SSCF) }\end{array}$ & None & $\begin{array}{c}0.51 \mathrm{~g} / \mathrm{L} \\
(30 \mathrm{mg} / \mathrm{g})\end{array}$ & [28] \\
\hline $\begin{array}{l}\text { Ethanol Red } \\
\text { (SSF) }\end{array}$ & $\mathrm{NaOH}$ & $\begin{array}{c}30.2 \mathrm{~g} / \mathrm{L} \\
(143 \mathrm{mg} / \mathrm{g})\end{array}$ & [29] \\
\hline $\begin{array}{c}\text { Scheffersomyces stipitis } \\
\text { (Evolved strain) } \\
\text { (SHF) }\end{array}$ & Low-moisture ammonia hydroxide & $\begin{array}{c}22.7 \mathrm{~g} / \mathrm{L} \\
\left(247 \mathrm{mg}^{\%} / \mathrm{g}\right)\end{array}$ & [1] \\
\hline $\begin{array}{l}\text { S. cerevisiae TISTR } 5339 \\
\text { (SHF) }\end{array}$ & $\mathrm{NaOH}$ & $\begin{array}{c}44.7 \mathrm{~g} / \mathrm{L} \\
(187.4 \mathrm{mg} / \mathrm{g}) \\
\left(298 \mathrm{mg} / \mathrm{g}^{\#}\right)\end{array}$ & This study \\
\hline
\end{tabular}

Notes: (1) SSF = simultaneous saccharification and fermentation, SSCF = simultaneous saccharification and co-fermentation, $\mathrm{SHF}=$ separate hydrolysis and fermentation. ${ }^{*} \mathrm{PF}=$ pentose fermentation, where ethanol from SSF was removed prior to $\mathrm{PF},{ }^{* *}$ ethanol concentration from glucose fraction via SSF by S. cerevisiae, ${ }^{\text {\# }}$ pretreated biomass and ${ }^{\%}$ converted from volume using ethanol density at $20{ }^{\circ} \mathrm{C}\left(789.2 \mathrm{~kg} / \mathrm{m}^{3}\right)$.

Treatment with $\mathrm{NaOH}$ alters Napier grass structure by causing swelling of the structures, while the acid-treated grass maintained a smooth surface, as evident in Figure 3b,c. The swelling is the result of a saponification reaction at the ester bonds between 4-O-methylglucuronic acid and xylan by $\mathrm{NaOH}$ [30]. The swelled structure allows enzymes to penetrate, resulting in a more efficient hydrolysis [31]. This explanation supports the results shown in Tables 2, 4 and 5 where susceptibility to cellulase hydrolysis of the grass was higher when treated with $\mathrm{NaOH}$ as compared to dilute acid. Severity of pretreatment has shown effects on the hydrolysis step. The use of mild pretreatments such as hot water and dilute $\mathrm{NaOH}$ resulted in low ethanol concentrations obtained even with further enzymatic hydrolysis of pretreated biomass [28,32]. However, it should be noted that a suitable strength of pretreatment is also important. A study on the pretreatment of switch grass showed that a high level of delignification reduces the cellulose accessibility to cellulase due to the change in cellulose structure that led to the reduction in available surface area for enzyme adsorption [13]. The result from that study explains our results in Figure 1a where the susceptibility appeared to decrease when $\mathrm{NaOH}$ exceeded $2 \mathrm{M}$. 
In addition, extra lignin removal in the grass pretreated with $\mathrm{NaOH}$ followed by $\mathrm{H}_{2} \mathrm{SO}_{4}$ (Table 6) did not enhance the susceptibility of the grass to cellulose hydrolysis. The susceptibility indicates an ability of cellulase to access and hydrolyse a structure. The results agreed with those reported earlier that the key parameter for hydrolysis of lignocellulosic materials was cellulose accessibility, rather than lignin content or crystallinity of the biomass $[12,13,16]$.

The effect of alkali and dilute acid on the susceptibility of the grass during pretreatment process reflects on the results of hydrolysis studies. Since the dilute acid pretreatment resulted in the pretreated grass with the structure that was less susceptible to hydrolysis by cellulase, as indicated by its low susceptibility value, the enzyme dosage required for its hydrolysis was much lower than that for the alkali-treated grasses (Table 9). Similar to the case of excessive delignification, a lesser area accessible by the enzyme resulted in lower sugars obtained from the hydrolysis of the grass pretreated by dilute acid. In addition, the lesser accessible area could cause the limit in hydrolysis even at low enzyme dosage, such that increase in enzyme dosage did not result in a further increase in reducing sugars as evident in Figure $4 \mathrm{~b}$. ANOVA of the acid pretreated grass in Table 8 also confirmed this result as the enzyme dosage did not exert a significant effect on the hydrolysis.

Regarding the fermentation for ethanol production, decrease in xylose during S. cerevisiae fermentation was not expected, as the yeast is not reported as a xylose-fermenting yeast. The decrease may be the result of xylose transport into the cells. Xylose intake through glucose transport system was formerly reported in S. cerevisiae [33]. In addition, S. cerevisiae also inherits xylose reductase and xylitol dehydrogenase activities. Xylose reductase is induced by xylose and xylitol produced accumulates without further conversion to ethanol [33,34].

When comparing the cultivations of S. cerevisiae via SHF and SSF (Table 10), it is evident that SHF yields higher ethanol concentration and productivity. The hydrolysis of Napier grass at its optimal temperature yields high sugar concentration, whereas the hydrolysis in SSF occurs at $30^{\circ} \mathrm{C}$ at which the enzyme has lower activity. A 24-h hydrolysis test of pretreated Napier grass at $30^{\circ} \mathrm{C}$ resulted in $119.1 \mathrm{~g} / \mathrm{L}$ reducing sugar in which contained $82.1 \mathrm{~g} / \mathrm{L}$ glucose and $14.1 \mathrm{~g} / \mathrm{L}$ xylose. These values were slightly lower than the hydrolysate used in SHF. The maximum specific growth rate in SSF was, in contrary, slightly higher than that in SHF. Substrate inhibition on growth could explain the result obtained, as glucose at the concentration higher than $80 \mathrm{~g} / \mathrm{L}$ showed an inhibition effect on $S$. cerevisiae [35]. Despite the higher ethanol obtained from SHF, the process involved the hydrolysis period, which resulted in a significantly lower overall ethanol productivity for the process. Reducing the hydrolysis time in SHF would improve this overall productivity value.

In SHF of $S$. shehatae, which is a xylose-fermenting yeast, the yeast utilized only $33 \%$ of the xylose. The issue should not relate to the presence of inhibitors normally found in acid hydrolysate, as we used enzymatic hydrolysis. This result contradicts our initial assumption that the yeast could effectively utilize xylose. We based the assumption on our previous study that showed the yeast's ability to ferment both glucose and xylose to ethanol [36]. However, the current work involved the use of higher concentration of sugars (in hydrolysate). It could be possible that the higher ethanol concentration at the time glucose depleted in this study could have a more negative effect to xylose transport than in our previous work.

The use of SHF and SSF in ethanol production by S. shehatae resulted differently from the cultivations of $S$. cerevisiae. In this case, the SSF by $S$. shehatae resulted in higher ethanol concentration regardless of a similar specific growth rate of the yeast between both fermentation techniques (Table 10). By comparing the ethanol production profiles during the first $24 \mathrm{~h}$ of fermentation (Figure 6), it is evident that the ethanol produced in SSF was higher than that in SHF, resulting also in a higher ethanol concentration obtained in SSF at the end of the fermentation. The faster ethanol production could be the result of lower sugar concentration during the fermentation that alleviated the substrate inhibition effect on product formation. The conversion yield of sugar in the hydrolysate appears more effective in SSF for S. shehatae as the ethanol was higher than that obtained from SHF regardless of the lower sugar obtained from hydrolysis at $30^{\circ} \mathrm{C}$. 


\section{Conclusions}

Napier grass has delivered satisfactory results as a second-generation feedstock for ethanol production. Pretreatment of the grass by $\mathrm{NaOH}$ is an important step for further hydrolysis by cellulase, both in SHF and SSF for ethanol production. The process for pretreatment involved the use of $1.99 \mathrm{M}$ $\mathrm{NaOH}$ at $95.7^{\circ} \mathrm{C}$ for $116 \mathrm{~min}$ with the grass loading of $15 \% \mathrm{w} / v$. After washing off the alkali, the grass could be used in ethanol production by S. cerevisiae via SHF or SSF, with SHF yielded a slightly higher ethanol concentration. The enzyme (Cellic ${ }^{\circledR} \mathrm{CTec} 2$ ) at the dosage of $40 \mathrm{FPU} / \mathrm{g}$ could be applied directly in SSF. The hydrolysate for SHF could be prepared using the same enzyme dosage to hydrolyse $15 \%$ $w / v$ of the pretreated grass at $50{ }^{\circ} \mathrm{C}$ for $117 \mathrm{~h}$ to obtain fermentable sugars. The overall process could yield $171-187 \mathrm{~g}$ of ethanol $/ \mathrm{kg}$ of Napier grass at the ethanol concentrations of $41-45 \mathrm{~g} / \mathrm{L}$.

Author Contributions: Conceptualization: M.B.K.; data curation: M.B.K.; formal analysis: M.B.K. and C.S.-K.; funding acquisition: M.B.K. and A.R.; investigation: C.S.-K.; methodology: M.B.K. and C.S.-K.; project administration: M.B.K. and C.S.-K.; resources: M.B.K. and A.R.; supervision: M.B.K. and A.R.; validation: M.B.K. and C.S.-K.; visualization: M.B.K.; writing—original draft: M.B.K.; writing—review and editing: M.B.K. and A.R. All authors have read and agreed to the published version of the manuscript.

Funding: This research was funded by (1) Thailand Research University Network under Bio-conversion group (2) Energy Conservation and Promotion Fund, Energy Policy and Planning Office (EPPO), Ministry of Energy Thailand (3) National Research Council of Thailand (NRCT), the Higher Education Research Promotion, and National Research University Project of Thailand through Biofuels Research Cluster of Khon Kaen University, project number NRU543030 and (4) TRF Senior Research Scholar, grant number RTA6280001.

Acknowledgments: The authors appreciate the donation of Napier grass from Department of Agronomy, Faculty of Agriculture, Khon Kaen University. C.S.-K. is grateful for her partial financial support from Center for Alternative Energy Research and Development. We would also like to thank Prawphan Yuvadetkun for her valuable assistance during the course of the project operation.

Conflicts of Interest: The authors declare no conflict of interest. The funders had no role in the design of the study; in the collection, analyses, or interpretation of data; in the writing of the manuscript, or in the decision to publish the results.

\section{References}

1. Dien, B.S.; Anderson, W.F.; Cheng, M.H.; Knoll, J.E.; Lamb, M.; O’Bryan, P.J.; Singh, V.; Sorensen, R.B.; Strickland, T.C.; Slininger, P.J. Field productivities of Napier grass for production of sugars and ethanol. ACS Sustain. Chem. Eng. 2020, 8, 2052-2060. [CrossRef]

2. De Favare, H.G.; de Abreu, J.G.; de Barros, L.V.; da Silva, F.G.; Ferreira, L.M.M.; Barelli, M.A.A.; Neto, I.M.d.S.; Cabral, C.E.A.; Peixoto, W.M.; Campos, F.I.d.S.; et al. Effect of Elephant grass Genotypes to Bioenergy production. J. Exp. Agric. Int. 2019, 38,1-11. [CrossRef]

3. Wijitphan, S.; Lowilai, P. Effects of cutting interval on yields and nutritive values of King Napier grass (Pennisetum purpureum cv. King grass) under Irrigation Supply. KKU Res. J. 2011, 16, 215-224.

4. Cardona, E.; Rios, J.; Pena, J.; Penuela, M.; Luis Rios, L. King Grass: A very promising material for the production of second generation ethanol in tropical countries. Biomass Bioenergy 2016, 95, 206-213. [CrossRef]

5. Kamarullah, S.H.; Marlina Mohd Mydin, M.M.; Omar, W.S.A.W.; Harith, S.S.; Noor, B.H.M.; Alias, N.Z.A.; Manap, S.; Mohamad, R. Surface morphology and chemical composition of Napier grass fibers. Malays. J. Anal. Sci. 2015, 19, 889-895.

6. Li, Y.; Zhang, Y.; Zheng, H.; Du, J.; Zhang, H.; Wu, J.; Huang, H. Preliminary evaluation of five elephant grass cultivars harvested at different time for sugar production. Chin. J. Chem. Eng. 2015, 23, 1188-1193. [CrossRef]

7. Mohammed, I.Y.; Abakr, Y.A.; Kazi, F.K.; Yusup, S.; Alshareef, I.; Soh, A.; Chin, S.A. Comprehensive characterization of Napier grass as a feedstock for thermochemical conversion. Energies 2015, 8, 3403-3417. [CrossRef]

8. Napier Grass. Available online: http://weben.dede.go.th/webmax/content/napier-grass (accessed on 6 April 2020).

9. Narinthorn, R.; Choorit, W.; Chisti, Y. Alkaline and fungal pretreatments for improving methane potential of Napier grass. Biomass Bioenergy 2019, 127, 105262. [CrossRef] 
10. Suaisom, P.; Patiroop Pholchana, P.; Aggarangsi, P. Holistic determination of suitable conditions for biogas production from Pennisetum purpureum $\mathrm{x}$ Pennisetum americanum liquor in anaerobic baffled reactor. J. Environ. Manag. 2019, 247, 730-737. [CrossRef]

11. Bensah, E.C.; Kádár, Z.; Mensah, M.Y. Ethanol production from hydrothermally-treated biomass from West Africa. BioResources 2015, 10, 6522-6537. [CrossRef]

12. Arantes, V.; Saddler, J.N. Cellulose accessibility limits the effectiveness of minimum cellulase loading on the efficient hydrolysis of pretreated lignocellulosic substrates. Biotechnol. Biofuels 2011, 4, 3. [CrossRef] [PubMed]

13. Rollin, J.A.; Zhu, Z.; Sathitsuksanoh, N.; Zhang, Y.-H.P. Increasing cellulose accessibility is more important than removing lignin: A comparison of cellulose solvent-based lignocellulose fractionation and soaking in aqueous ammonia. Biotechnol. Bioeng. 2011, 108, 22-30. [CrossRef] [PubMed]

14. Eliana, C.; Jorge, R.; Juan, P.; Luis, R. Effects of the pretreatment method on enzymatic hydrolysis and ethanol fermentability of the cellulosic fraction from elephant grass. Fuel 2014, 118, 41-47. [CrossRef]

15. Pensri, B.; Aggarangsi, P.; Chaiyaso, T.; Chandet, N. Potential of fermentable sugar production from Napier cv. Pakchong 1 grass residue as a substrate to produce bioethanol. Energy Procedia 2016, 89, 428-436. [CrossRef]

16. Phitsuwan, P.; Sakka, K.; Ratanakhanokchai, K. Structural changes and enzymatic response of Napier grass (Pennisetum purpureum) stem induced by alkaline pretreatment. Bioresour Technol. 2016, 218, 247-256. [CrossRef]

17. Yasuda, M.; Nagai, H.; Takeo, K.; Ishii, Y.; Ohta, K. Bio-ethanol production through simultaneous saccharification and co-fermentation (SSCF) of a low-moisture anhydrous ammonia (LMAA)-pretreated napiegrass (Pennisetum purpureum Schumach). Springerplus 2014, 3, 333. [CrossRef]

18. Yasuda, M.; Takeo, K.; Nagai, H.; Uto, T.; Yui, T.; Matsumoto, T.; Ishii, Y.; Ohta, K. Enhancement of ethanol production from Napiergrass (Pennisetum purpureum Schumach) by a low-moisture anhydrous ammonia pretreatment. J. Sustain. Bioenergy Syst. 2013, 3, 179-185. [CrossRef]

19. Bohórquez, C.; González, E.A.; Reina, M.R. Effect of pretreatment dilute acid-Peroxide on napier grass (Pennisetum purpureum schumach) to enhance reducing sugar yield by enzymatic hydrolysis. AVANCES Investigación en Ingeniería 2014, 11, 48-55. [CrossRef]

20. Camesasca, L.; Ramírez, M.B.; Guigou, M.; Ferrari, M.D.; Lareo, C. Evaluation of dilute acid and alkaline pretreatments, enzymatic hydrolysis and fermentation of napiergrass for fuel ethanol production. Biomass Bioenergy 2015, 74, 193-201. [CrossRef]

21. Scholl, A.L.; Menegol, D.; Pitarelo, A.P.; Fontana, R.C.; Filho, A.Z.; Ramos, L.P.; Dillon, A.J.P.; Camassola, M. Ethanol production from sugars obtained during enzymatic hydrolysis of elephant grass (Pennisetum purpureum, Schum.) pretreated by steam explosion. Bioresour Technol. 2015, 192, 228-237. [CrossRef]

22. Meneses, L.R.; Otor, O.F.; Bonturi, N.; Orupõld, K.; Kikas, T. Bioenergy yields from sequential bioethanol and biomethane production: An optimized process flow. Sustainability 2020, 12, 272. [CrossRef]

23. Sluiter, A.; Hames, B.; Hyman, D.; Payne, C.; Ruiz, R.; Scarlata, C.; Sluiter, J.; Templeton, D.; Wolfe, J. Determination of Total Solids in Biomass and Total Dissolved Solids in Liquid Process Samples; Technical Report NREL/TP-510-42618; National Renewable Energy Laboratory: Golden, CO, USA, 2011.

24. Sun, S.; Sun, S.; Cao, X.; Sun, R. The role of pretreatment in improving the enzymatic hydrolysis of lignocellulosic materials. Bioresour. Technol. 2016, 199, 49-58. [CrossRef] [PubMed]

25. Dong, M.; Wang, S.; Xu, F.; Wang, J.; Yang, N.; Li, Q.; Chen, J.; Li, W. Pretreatment of sweet sorghum straw and its enzymatic digestion: Insight into the structural changes and visualization of hydrolysis process. Biotechnol. Biofuels 2019, 12, 276. [CrossRef] [PubMed]

26. Zhang, H.; Wei, W.; Zhang, J.; Huang, S.; Xie, J. Enhancing enzymatic saccharification of sugarcane bagasse by combinatorial pretreatment and Tween 80. Biotechnol. Biofuels 2018, 11, 309. [CrossRef]

27. Menegol, D.; Fontana, R.C.; Dillon, A.J.P.; Camassola, M. Second-generation ethanol production from elephant grass at high total solids. Bioresour. Technol. 2016, 211, 280-290. [CrossRef]

28. Liu, Y.K.; Chen, W.C.; Huang, Y.C.; Chang, Y.K.; Chu, I.M.; Tsai, S.L.; Wei, Y.H. Production of bioethanol from Napier grass via simultaneous saccharification and co-fermentation in a modified bioreactor. J. Biosci. Bioeng. 2017, 124, 184-188. [CrossRef]

29. Tsai, M.H.; Lee, W.C.; Kuan, W.C.; Sirisansaneeyakul, S.; Savarajara, A.A. Evaluation of different pretreatments of Napier grass for enzymatic saccharification and ethanol production. Energy Sci. Eng. 2018, 6, 683-692. [CrossRef] 
30. Tarkow, H.; Feist, W.C. A mechanism for improving the digestibility of lignocellulosic materials with dilute alkali and liquid ammonia. In ACS Advances in Chemistry Series; Hajny, G.J., Reese, E.T., Eds.; American Chemical Society: Washington, DC, USA, 1969; Volume 95, pp. 197-218.

31. Hendriks, A.T.W.M.; Zeeman, G. Review Pretreatments to enhance the digestibility of lignocellulosic biomass. Bioresour. Technol. 2009, 100, 10-18. [CrossRef]

32. Soares, I.B.; Marques, O.M.; Benachour, M.; Abreu, C.A.M.d. Ethanol production by enzymatic hydrolysis of elephant grass. J. Life Sci. 2011, 5, 157-161.

33. Van Zyl, C.; Prior, B.A.; Kilian, S.G.; Kock, J.L.F. D-xylose utilization by Saccharomyces cerevisiae. J. Gen. Microbiol. 1989, 135, 2791-2798. [CrossRef]

34. Batt, C.A.; Carvallo, S.; Eassond, D.D.; Akedom, M.; Sinskeya, A.J. Direct evidence for a xylose metabolic pathway in Saccharomyces cerevisiae. Biotechnol. Bioeng. 1986, 28, 549-553. [CrossRef] [PubMed]

35. Zhang, Q.; Wu, D.; Lin, Y.; Wang, X.; Kong, H.; Tanaka, S. Substrate and product inhibition on yeast performance in ethanol fermentation. Energy Fuels 2015, 29, 1019-1027. [CrossRef]

36. Yuvadetkun, P.; Boonmee, M. Ethanol production capability of Candida shehatae in mixed sugars and rice straw hydrolysate. Sains Malays. 2016, 45, 581-587.

(C) 2020 by the authors. Licensee MDPI, Basel, Switzerland. This article is an open access article distributed under the terms and conditions of the Creative Commons Attribution (CC BY) license (http://creativecommons.org/licenses/by/4.0/). 